\title{
KEDUDUKAN BADAN HUKUM RUMAH SAKIT PRIVAT DIHUBUNGKAN DENGAN FUNGSI SOSIO EKONOMI
}

\author{
Wahyudi \\ Politeknik Piksi Ganesha Bandung \\ Email : wahyudiyurispruden@yahoo.co.id
}

\begin{abstract}
Society as users of health services organized by hospitals are entitled to receive services in plenary by not getting any difference of legal entity of hospital managers. The main goal of heal th care hospitals include the preventive, curative, rehabilitative and promotive to all levels of society in accordance with the socio-economic function that prioritizes social functioning compared with economic function. The legal entity of hospital management in the form of foundations, associations and limited liability companies. Research in this paper is a normative juridical research, which studied the approach of legislation (the statute approach) means that a problem will be seen from the legal aspect by studying the legislation. And also the method by way of literature study (library research). The research concludes that there are three (3) legal entity that manages private hospitals are more widely used by the public, namely foundations, associations and limited liability companies. Limited liability company that manages the hospital has the main purpose for profit or economic function takes precedence while legal entities of foundations and associations in managing hospitals prioritize socio-economic functions.
\end{abstract}

Keyword : Hospital, Private Corporate, Socio Economy

\begin{abstract}
Abstrak
Masyarakat sebagai pengguna pelayanan kesehatan yang diselenggarakan oleh rumah sakit berhak untuk menerima layanan kesehatan secara paripurna dengan tidak mendapatkan perbedaan dari pengelola rumah sakit. Tujuan utama dari rumah sakit dalam pelayanan kesehatan meliputi upaya preventif, kuratif, rehabilitatif dan promotif kepada seluruh lapisan masyarakat sesuai dengan fungsi sosial-ekonomi yang mengutamakan fungsi sosial dibandingkan dengan fungsi ekonomi. Badan hukum pengelola rumah sakit dalam bentuk yayasan, perkumpulan dan perseroan terbatas. Penelitian dalam penelitian yuridis normatif, yaitu dikaji dengan pendekatan perundang-undangan (the statute approach) artinya suatu masalah akan dilihat dari
\end{abstract}


aspek hukumnya dengan menelaah peraturan perundang-undangan, selain itu juga metode dengan cara studi kepustakaan (library research). Hasil penelitian menyimpulkan bahwa terdapat tiga (3) badan hukum yang mengelola rumah sakit privat yang lebih banyak digunakan oleh masyarakat yaitu yayasan, perkumpulan dan perseroan terbatas. Perseroan terbatas yang mengelola rumah sakit memiliki tujuan utama mencari keuntungan atau fungsi ekonomi diutamakan sedangkan badan hukum yayasan dan perkumpulan dalam mengelola rumah sakit mengutamakan fungsi sosio ekonomi.

Kata Kunci : Rumah Sakit, Badan Usaha Privat, Sosio Ekonomi

\section{Pendahuluan}

Kebutuhan manusia terus semakin bertambah dengan pesatnya kemajuan teknologi dan ilmu pengetahuan, kesehatan merupakan salah satu kebutuhan pokok yang menjadi prioritas. Dengan perkembangan zaman dan perkembangan ilmu pengetahuan dalam bidang kesehatan membuat kebutuhan kesehatan menjadi semakin mahal. Penyelenggara pelayanan kesehatan mulai dari klinik kesehatan, puskesmas dan rumah sakit.

Rumah sakit merupakan suatu unit usaha jasa yang memberikan jasa pelayanan sosial di bidang medis klinis. Dalam memberikan pelayanan kesehatan, aspek-aspek pelayanan kesehatan diberikan melalui diagnosis, pengobatan, perawatan dan pendidikan kesehatan ${ }^{1}$. Tujuan utama dari rumah sakit pada dasarnya menyelenggarakan pelayanan kesehatan secara paripurna. Pengelolaan unit usaha rumah sakit memiliki keunikan tersendiri karena selain sebagai unit bisnis, usaha rumah sakit juga nemiliki misi sosial, disamping pengelolaan rumah sakit juga sangat tergantung pada status kepemilikan rumah sakit. Rumah sakit merupakan institusi yang padat karya, padat modal dan juga padat teknologi sehingga untuk berjalannya suatu rumah sakit memerlukan biaya yang tinggi.

Berdasarkan Pasal 20 ayat (1) Undang-undang Nomor 44 Tahun 2009 Tentang Rumah Sakit membagi 2 jenis rumah sakit, berdasarkan pengelolaannya rumah sakit dapat dibagi menjadi rumah sakit publik dan rumah sakit privat. rumah sakit publik dikelola oleh pemerintah dan pemerintah daerah yang berdasarkan pengelolaan badan

\footnotetext{
${ }^{1}$ Soerjono Soekanto, Pengantar Hukum Kesehatan, Cv. Ramedja Karya, Bandung, 1987, hlm. 131.
} 
layanan umum dan badan layanan umum daerah yang bersifat nirlaba sedangkan rumah sakit privat dikelola badan hukum dengan tujuan profit atau mencari keuntungan yang berbentuk perseroan terbatas atau persero.

Rumah sakit publik yang dikelola pemerintah atau pemerintah daerah dalam melayani masyarakat mempunyai fungsi sosial sehingga sering terjadi yang berobat ke rumah sakit pemerintah kebanyakan kelas menengah ke bawah. Dengan adanya keterbatasan sumber dana, serta berbagai aturan dan birokrasi yang harus dihadapi terkadang pelayanannya tidak seperti rumah sakit privat.

Rumah sakit pemerintah lebih tepat sebagai klasifikasi non bisnis, namun rumah sakit swasta tidak seluruhnya diklasifikasikan dalam kelompok non bisnis. Beberapa rumah sakit masih memiliki kualitas jasa layanan yang masih sangat memprihatinkan. Hal ini antara lain disebabkan karena keterbatasan sumber daya baik sumber daya finansial maupun sumber daya non finansial. Tuntutan peningkatan kualitas jasa layanan membutuhkan berbagai dana investasi yang tidak sedikit. Kenaikan tuntutan kualitas jasa layanan rumah sakit harus dibarengi dengan profesionalisme dalam pengelolaannya. Perkembangan pengelolaan rumah sakit, baik dari aspek manajemen maupun operasional sangat dipengaruhi oleh berbagai tuntutan dari lingkungan, yaitu lingkungan eksternal dan internal. Tuntutan eksternal antara lain adalah dari para stakeholder bahwa rumah sakit dituntut untuk memberikan pelayanan kesehatan yang bermutu, dan biaya pelayanan kesehatan terkendali sehingga akan berujung pada kepuasan pasien. Tuntutan dari pihak internal antara lain adalah pengendalian biaya.

Biaya kesehatan cenderung terus meningkat, dan rumah sakit dituntut untuk secara mandiri mengatasi masalah tersebut. Peningkatan biaya kesehatan ini menyebabkan permasalahan tersendiri bagi rumah sakit pemerintahan karena rumah sakit pemerintah memiliki segmen layanan kesehatan untuk kalangan menengah ke bawah. Akibatnya rumah sakit pemerintah diharapkan menjadi rumah sakit yang murah dan bermutu.

Perbedaan yang sangat mendasar antara rumah sakit publik dengan rumah sakit privat yaitu pengelolaan keuangan. Rumah sakit publik tidak diperkenankan mencari keuntungan, sebaliknya rumah sakit privat mencari keuntungan. Akan tetapi 
berdasarkan Peraturan Menteri Kesehatan Nomor 920 / Menkes / Per / XII/1986 Tentang Upaya Pelayanan Kesehatan Swasta di Bidang Medik, sebagaimana telah diubah dengan Peraturan Menteri Kesehatan Nomor 084 / Menkes / Per / II / 1990 Tentang Perubahan atas Peraturan Menteri Kesehatan RI Nomor 920 / Menkes / Per/XII/1986 Tentang Upaya Pelayanan Kesehatan Swasta di Bidang Medik dan Peraturan Menteri Kesehatan Nomor 378 Tahun 1993 Tentang Pelaksanaan Fungsi Sosial Rumah Sakit Swasta mengamanatkan bahwa rumah sakit swasta harus mempunyai fungsi sosial.

Rumah sakit publik maupun rumah sakit privat harus berbadan hukum agar dapat melakukan perbuatan hukum secara sah. Perbuatan hukum rumah sakit tersebut dalam hubungan dengan pihak internal maupun eksternal. Hubungan internal rumah sakit menyangkut dengan kepegawaian rumah sakit diantaranya yaitu staff medis dan non medis, sedangkan pihak eksternal rumah sakit yaitu yang melibatkan pihak luar rumah sakit dalam bentuk kerjasama pengadaan alat kesehatan, tenaga kerja outsourching ataupun penerimaan hibah dari dalam maupun luar negeri.

Bentuk badan hukum rumah sakit tersebut dapat berupa perseorangan, perkumpulan, commanditer venonschaap, yayasan dan perseroan terbatas. Rumah sakit pemerintah atau rumah sakit publik yang dimiliki pemerintah daerah dalam bentuk badan usaha milik daerah sedangkan rumah sakit privat seperti halnya badan hukum pada umumnya. Perbedaan dalam tujuan utama pelayanan kesehatan rumah sakit privat erat kaitan dengan persaingan usaha dalam pelayanan kesehatan sehingga fungsi sosial sebagai tujuan utama mulai bergeser dengan fungsi ekonomi.

Rumah sakit adalah salah satu jenis sarana pelayanan kesehatan, yang tugas utamanya melayani kesehatan perorangan disamping tugas pelayanan lainnya ${ }^{2}$. Menurut Undang-Undang Republik Indonesia Nomor 44 Tahun 2009 Tentang Rumah Sakit, rumah sakit adalah institusi pelayanan kesehatan yang menyelenggarakan pelayanan kesehatan perorangan secara paripurna yang menyediakan pelayanan rawat inap, rawat jalan, dan gawat darurat. Rumah sakit juga merupakan tempat menyelenggarakan upaya kesehatan yaitu setiap kegiatan untuk memelihara dan meningkatkan kesehatan serta bertujuan untuk mewujudkan derajat kesehatan yang optimal bagi masyarakat.

\footnotetext{
${ }^{2}$ Endang Wahyati Yustina, Mengenal Hukum Rumah Sakit, Keni Media, Bandung, 2012, hlm. 8
} 
Menurut Undang-Undang Nomor 44 Tahun 2009 Tentang Rumah Sakit, rumah sakit mempunyai tugas memberikan pelayanan kesehatan perorangan secara paripurna. Pelayanan kesehatan paripurna adalah pelayanan kesehatan yang meliputi promotif, preventif, kuratif, dan rehabilitatif. Rumah sakit dalam upaya pelayanan kesehatan dilakukan dengan pendekatan pemeliharaan, peningkatan kesehatan (promotif), pencegahan penyakit (preventif), penyembuhan penyakit (kuratif) dan pemulihan (rehabilitatif) yang dilaksanakan secara serasi dan terpadu serta berkesinambungan. Pelayanan kesehatan secara paripurna tersebut harus terukur dan mempunyai target pencapaian yang optimal serta realistis yang dapat dilakukan.

Berdasarkan Undang-Undang Nomor 44 Tahun 2009, rumah sakit umum mempunyai fungsi:

a. penyelenggaraan pelayanan pengobatan dan pemulihan kesehatan sesuai dengan standar pelayanan rumah sakit.

b. pemeliharaan dan peningkatan kesehatan perorangan melalui pelayanan kesehatan yang paripurna.

c. penyelenggaraan pendidikan dan pelatihan sumber daya manusia dalam rangka peningkatan kemampuan dalam pemberian pelayanan kesehatan.

d. penyelenggaraan penelitian dan pengembangan serta penapisan teknologi bidang kesehatan dalam rangka peningkatan pelayanan kesehatan dengan memperhatikan etika ilmu pengetahuan bidang kesehatan.

Berdasarkan Undang-Undang Republik Indonesia Nomor 44 Tahun 2009 Tentang Rumah Sakit, rumah sakit dapat dibagi berdasarkan jenis pelayanan dan pengelolaannya yaitu berdasarkan jenis pelayanan, terdiri dari rumah sakit umum, memberikan pelayanan kesehatan pada semua bidang dan jenis penyakit, rumah sakit khusus, memberikan pelayanan utama pada satu bidang atau satu jenis penyakit tertentu berdasarkan disiplin ilmu, golongan umur, organ, jenis penyakit, atau kekhususan lainnya dan berdasarkan pengelolaannya yaitu rumah sakit publik, dapat dikelola oleh pemerintah, pemerintah daerah, dan badan hukum yang bersifat nirlaba. Rumah sakit publik yang dikelola pemerintah dan pemerintah daerah diselenggarakan berdasarkan pengelolaan Badan Layanan Umum atau Badan Layanan Umum Daerah sesuai dengan ketentuan peraturan perundang-undangan, rumah sakit privat, dikelola oleh badan hukum dengan tujuan profit yang berbentuk Perseroan Terbatas atau Persero. 


\section{Klasifikasi Rumah Sakit Umum}

Berdasarkan Undang-Undang Republik Indonesia No. 44 Tahun 2009 Tentang Rumah Sakit, dalam rangka penyelenggaraan pelayanan kesehatan secara berjenjang dan fungsi rujukan, rumah sakit umum diklasifikasikan berdasarkan fasilitas dan kemampuan pelayanan rumah sakit:

a. Rumah Sakit umum kelas A, adalah rumah sakit umum yang mempunyai fasilitas dan kemampuan pelayanan medik spesialistik luas dan subspesialistik luas.

b. Rumah Sakit umum kelas B, adalah rumah sakit umum yang mempunyai fasilitas dan kemampuan pelayanan medik sekurang-kurangnya sebelas spesialistik dan subspesialistik luas.

c. Rumah Sakit umum kelas C, adalah rumah sakit umum yang mempunyai fasilitas dan kemampuan pelayanan medik spesialistik dasar.

d. Rumah Sakit umum kelas D, adalah rumah sakit umum yang mempunyai fasilitas dan kemampuan pelayanan medik dasar

2. Badan Usaha berbentuk Badan Hukum

Karakteristik suatu badan hukum yaitu terdapat pemisahan kekayaan pemilik dengan kekayaan badan usaha, sehingga pemilik hanya bertanggung jawab sebatas harta yang dimilikinya, badan usaha yang berbentuk Badan Hukum terdiri dari :

a. Perseroan Terbatas

Berdasarkan Undang-undang Nomor 40 Tahun 2007 Tentang Perseroan Terbatas, Perseroan Terbatas adalah badan usaha yang berbentuk badan hukum yang merupakan persekutuan modal, didirikan berdasarkan perjanjian, dan melakukan kegiatan usaha dengan modal dasar yang seluruhnya terbagi dalam saham. Sebagai badan hukum, perseroan terbatas dianggap layaknya orang-perorangan secara individu yang dapat melakukan perbuatan hukum sendiri, memiliki harta kekayaan sendiri, dan dapat dituntut serta menuntut di depan pengadilan. Unsur unsur suatu Perseroan Terbatas adalah ${ }^{3}$ :

1. Badan hukum

2. Persekutuan modal

3. Didirikan berdasarkan perjanjian

4. Melakukan kegiatan usaha

\footnotetext{
${ }^{3}$ Man S. Satrawidjaja, Peseroan Terbatas Menurut Tiga Undang - Undang Jilid 1, Bandung PT. Alumni, 2010, $\operatorname{lm} 14$.
} 
5. Modal dasar terbagi atas saham

b. Yayasan

Berdasarkan Undang-Undang Nomor 16 Tahun 2001 sebagaimana diubah dengan Undang-Undang Nomor 28 Tahun 2008 Tentang Yayasan, yayasan adalah badan hukum yang terdiri atas kekayaan yang dipisahkan dan diperuntukan untuk mencapai tujuan tertentu di bidang sosial, keagamaan dan kemanusiaan, yang tidak mempunyai anggota.

\section{c. Koperasi}

Berdasarkan Undang-Undang Nomor 17 Tahun 2012 Tentang Perkoperasian, koperasi adalah badan hukum yang didirikan oleh orang perseorangan atau badan hukum koperasi, dengan pemisahan kekayaan para anggotanya sebagai modal untuk menjalankan usaha, yang memenuhi aspirasi dan kebutuhan bersama di bidang ekonomi, sosial, dan budaya sesuai dengan nilai dan prinsip koperasi.

\section{d. Badan Usaha Milik Negara (BUMN)}

Berdasarkan Undang - Undang Nomor 19 Tahun 2003 Tentang Badan Usaha Milik Negara, BUMN adalah badan usaha yang seluruh atau sebagian besar modalnya dimiliki oleh Negara melalui penyertaan secara langsung yang berasal dari kekayaan Negara yang dipisahkan.

\section{Badan Usaha bukan berbentuk Badan Hukum}

Lain halnya dengan badan usaha yang bukan berbentuk badan hukum, pada bentuk badan usaha ini, tidak terdapat pemisahan antara kekayaan badan usaha dengan kekayaan pemiliknya, badan usaha bukan berbentuk badan hukum terdiri dari:

a. Persekutuan Perdata adalah suatu perjanjian di mana dua orang atau lebih mengikatkan diri untuk memasukkan sesuatu ke dalam persekutuan dengan maksud untuk membagi keuntungan yang terjadi karenanya. Para sekutu bertanggung jawab secara pribadi atas Persekutuan Perdata. 
b. Firma adalah suatu Perseroan yang didirikan untuk melakukan suatu usaha di bawah nama bersama. Para anggota memiliki tanggung jawab renteng terhadap Firma.

c. Persekutuan Komanditer (CV) adalah terdiri dari pesero aktif dan pesero pasif/komanditer. Pesero Aktif bertanggung jawab sampai dengan harta pribadi, sedangkan pesero pasif hanya bertanggung jawab sebesar modal yang telah disetorkan ke dalam CV.

Jenis penelitian pada penulisan ini adalah penelitian yuridis normatif, yaitu dikaji dengan pendekatan perundang-undangan (the statute approach) artinya suatu masalah akan dilihat dari aspek hukumnya dengan menelaah peraturan perundangundangan, selain itu juga metode dengan cara studi kepustakaan (library research) yaitu dengan cara melakukan analisis terhadap bahan-bahan pustaka berkaitan dengan permasalahan diatas.

\section{Pembahasan}

Perkembangan teknologi kesehatan semakin canggih, penemuan-penemuan tentang pelayanan kesehatan semakin banyak. Penemuan obat baru dan alat-alat penunjang kesehatan semakin beragam, inovasi-inovasi dalam pengobatan medis semakin banyak. Adanya perkembangan kemajuan teknologi kesehatan tersebut mempermudah tenaga kesehatan dalam melayani pasien-pasien di rumah sakit. Selain mempermudah juga mempersulit keuangan dari rumah sakit mengingat teknologi penunjang kesehatan tersebut sangat mahal, sehingga tidak semua rumah sakit memiliki alat-alat kesehatan canggih.

Rumah sakit privat kendala utama yang dihadapi terkait dengan persoalan permodalan, rumah sakit yang mempunyai modalyang kuat dapat dengan mudah membeli alat-alat penunjang kesehatan terbarau, tercanggih sebaliknya dengan rumah sakit yang mempunyai modal terbatas akan sulit mendapatkan alat penunjang kesehatan terbaru. Begitupula dengan persoalan keuangan untuk menggaji karyawannya, staf medis yang telah memperoleh gelar spesialis tentu akan lebih memilih rumah sakit yang memberikan fasilitas ataupun gaji yang lebih baik.

Keterkaitan dengan kebutuhan permodalan yang tinggi dan fungsi sosial rumah sakit yang tetap harus dijalankan dapat merubah tujuan utama badan hukum pengelola rumah sakit sehingga terdapat perbedaan yang mencolok antara bentuk badan hukum yayasan dan perseroan terbatas sebagai badan pengelola rumah sakit. 
Berdasarkan Pasal 1 Undang-undang Nomor 16 Tahun 2001 Tentang Yayasan, menyatakan bahwayayasan adalah badan hukum yang terdiri atas kekayaan yang dipisahkan dan diperuntukkan untuk mencapai tujuan tertentu dibidang sosial keagamaan dan kemanusiaan yang tidak mempunyai anggota. Berdasarkan pengertian yayasan tersebut, yayasan diberikan batasan yang jelas dan diharapkan masyarakat dapat memahami bentuk dan tujuan pendirian yayasan tersebut. Sehingga tidak terjadi kekeliruan persepsi tentang yayasan dan tujuan diberikannya yayasan yang geraknya terbatas di bidang sosial, keagamaan dan kemanusiaan sehingga tidak dipakai sebagai kendaraan untuk mencari keuntungan. Yayasan dipandang sebagai subyek hukum karena memenuhi hal-hal sebagai berikut:
a. Yayasan adalah perkumpulan orang.
b. Yayasan dapat melakukan perbuatan hukum dalam hubungan hukum.
c. Yayasan mempunyai harta kekayaan sendiri.
d. Yayasan mempunyai pengurus.
e. Yayasan mempunyai maksud dan tujuan.
f. Yayasan mempunyai kedudukan hukum (domisili) tempat.
g. Yayasan dapat digugat atau menggugat di muka pengadilan.

Unsur-unsur yang tersebut di atas dapat diberikan suatu kesimpulan bahwa yayasan memenuhi syarat sebagai badan hukum dimana yayasan memiliki harta kekayaan sendiri, dapat melakukan perbuatan hukum dalam hubungan hukum, memiliki maksud dan tujuan serta unsur-unsur lainya sehingga yayasan persamakan statusnya dengan orang- perorangan. Yayasan sebagai sebuah badan hukum mempunyai suatu badan yang membentuk kehendaknya dengan perantara alat-alat atau organ-organ badan tersebut. Sehingga segala tindakan dari yayasan diwakilkan oleh organ-organ pengurusnya, apa yang diputuskan oleh organ tersebut adalah keputusan dari yayasan itu.

Sebagian rumah sakit privat didirikan oleh lembaga-lembaga atau yayasan, khususnya dengan latar belakang keagamaan atau lembaga-lembaga sosial lainnya, yang biasanya diprakarsai oleh kalangan masyarakat atau orang-orang yang terhormat. Rumah sakit seperti ini membawa misi sosial dan karena itu tidak mencari keuntungan. Mungkin karena sifat non-profit making inilah, ada kesan bahwa rumah sakit seperti ini dikelola semata-mata mengutamakan pelayanan medis pasien-pasien 
yang dirawat. Kerugian yang ada biasanya akan ditangani lembaga-lembaga keagamaan/ sosial yang bersangkutan, dari donasi/sumbangan yang diperolehnya.

Yayasan sebagai badan hukum pengelola rumah sakit tetap mempunyai perbedaan dengan unit kegiatan yang dimiliki yayasan lainnya, misalnya pengelolaan pelayanan pendidikan yang diselenggarakan oleh yayasan sangat berbeda dengan pengelolaan rumah sakit. Organ dalam pelayanan kesehatan dan pelayanan kependidikan yang dikelola oleh yayasan sangat berbeda.

Ada tiga organ penting dengan tugas dan wewenang dalam pengelolaan rumah sakit, yaitu:

1. Pemilik rumah sakit / yayasan / Governing Board.

2. Direksi rumah sakit.

3. Staf kedokteran (Medical Staff).

Keberadaan rumah sakit sangat berperan penting bagi peningkatan taraf kesehatan masyarakat, pada zaman dahulu rumah sakit adalah lembaga sosial murni yang melakukan pelayanan kesehatan bagi masyarakat secara gratis, sehingga dianggap sebagai lembaga sosial yang kebal hukum berdasarkan doctrin of charitable immunity. Namun dengan adanya perubahan paradigma, rumah sakit merupakan institusi yang padat karya, padat modal, padat profesi dan padat teknologi sehingga pengelolaan rumah sakit tidak semata-mata sebagai unit sosial tetapi sebagai unit sosio-ekonomi. Hal tersebut sesuai dengan Pasal 5 ayat (1) Petunjuk Pelaksanaan Kode Etik Rumah Sakit Indonesia (KODERSI), rumah sakit sebagai sarana pelayanan kesehatan adalah merupakan "unit sosio ekonomi" yang harus mengutamakan tugas kemanusiaan dan mendahulukan fungsi sosialnya, bukan bertujuan mencari keuntungan semata.

Pada dasarnya rumah sakit disamping tetap mempunyai tanggung jawab sosial yaitu memberikan jasa pertolongan kesehatan kepada masyarakat yang tidak terbatas tetapi dalam pengelolaan keuangannya tetap menerapkan prinsip-prinsip ekonomi. Dalam prinsip ekonomi, suatu institusi untuk dapat menjalankan roda kegiatannya tidak boleh mengalami kerugian. Dengan demikian fungsi sosial tetap berjalan dengan melayani pertolongan tak terbatas dan juga lembaga ekonominya tetap berjalan 
sehingga biaya operasional rumah sakit tetap terjaga demi kelangsungan pelayanan kesehatan rumah sakit itu sendiri.

Akan tetapi apabila pemerintah mampu menyediakan dana untuk membiayai operasional rumah sakit, sudah seharusnya memberikan rumah sakit tersebut tidak membebankan biaya kepada pasien karena sudah ditanggung negara, hal tersebut sangat sulit diterapkan di Indonesia karena kemampuan Negara belum memadai untuk melakukan hal demikian.

Subsidi silang menjadi alternatif yang paling sesuai dengan prinsip rumah sakit yang menganut unit sosio-ekonomi, pasien yang mampu harus membayar biaya sedangkan pasien yang tidak mampu dibebaskan dari biaya perawatan maupun pengobatan dengan mutu pelayanan yang optimal atau sama tanpa membedakan pasien yang bayar maupun yang tidak. Faktanya masih ada perbedaan pelayanan terhadap pasien yang miskin, karena tidak membayar sehingga pelayanan tidak dilakukan secara maksimal bahkan dibawah standar.

Badan hukum yayasan yang mengelola rumah sakit dalam anggaran dasar maupun anggaran rumah tangga apabila terdapat ketentuan yang memperbolehkan untuk mendapatkan bantuan dana dari pemerintah maupun pihak non pemerintah dapat memperoleh bantuan dana maupun alat penunjang kesehatan berdasarkan permohonan dari yayasan tersebut untuk menambah permodalan. Tujuan pelayanan kesehatan sebenarnya mencakup tercapainya equity. Tujuan ini sangat penting karena kesehatan adalah hak asasi yang paling mendasar bagi setiap individu. Equity yang dimaksudkan adalah egalitarian equity dan social equity (keadilan sosial yang adil dan merata ). Egalitarian equity pada dasarnya merupakan paham bahwa setiap orang harus dapat menerima pelayanan kesehatan sesuai dengan kemampuan membayar.

Sejalan dengan kemajuan dan perkembangan ilmu teknologi kedokteran rumah sakit telah berkembang dari suatu lembaga kemanusiaan, keagamaan dan sosial murni menjadi suatu lembaga yang lebih mengarah dan lebih berorientasi pada bisnis terlebih-lebih setelah diperbolehkannya para pemodal untuk mendirikan rumah sakit dibawah badan hukum yang bertujuan mencari laba ( for profit), yang merupakan kenyataan bahwa rumah sakit memang merupakan suatu lembaga yang padat modal, padat karya dan padat ilmu dan teknologi. Dalam pengelolaan rumah sakit guna mencapai efisiensi dan efektifitas yang tinggi memerlukan profesionalisme yang tinggi serta pengelolaan bisnis yang modern. Rumah sakit merupakan suatu lembaga yang 
berfungsi mewujudkan pranata upaya peleyanan kesehatan terbesar pada masyarakat dijaman moderen ini. Rumah sakit didirikan sebagai suatu tempat untuk memenuhi berbagai permintaan pasien dan dokter, agar penyelesaian masalah kesehatan dapat melaksanakan dengan baik. Perkembangannya sekarang ini, Rumah Sakit juga menjadi sarana untuk praktek, pengembangan ilmu pengetahuan dan teknologi kedokteran meskipun tidak seluruhnya.

Kompleksitas masalah kualitas pelayanan rumah sakit tidak saja terkait dengan keterbatasan sumber daya dan lingkungan, tetapi juga bersumber dari perbedaan persepsi diantara pemakai jasa pelayanan, petugas kesehatan, dan pemerintah atau penyandang dana terhadap organisasi rumah sakit sangatlah unik dan kompleks. Peranan rumah sakit yang semula tidak mencari keuntungan berubah dengan cepat, Rumah sakit menjadi suatu lembaga yang berperan sebagai organisasi pelayanan kesehatan, namun untuk mengantisipasi melonjaknya tarif pelayanan kesehatan, pemerintah membuat aturan-aturan untuk membatasinya, bahkan mendirikan rumah sakit umum sebagai pusat pelayanan kesehatan milik pemerintah, dan karena peruntukannya untuk umum maka termasuk kategori non profit atau tidak mencari keuntungan. Rumah sakit yang dikelola oleh pemerintah seringkali terkendala oleh dana yang belum dikeluarkan melalui APBN maupun APBD karena harus melalui mekanisme birokrasi sedangkan pelayanan terus berjalan sehingga biaya yang ditanggung oleh rumah sakit tersebut semakin meningkat. Selain yayasan sebagai badan hukum pengelola rumah sakit yang bertujuan utama mengedepankan fungsi sosial juga ada badan hukum perhimpunan yang mengelola rumah sakit nertujuan non profit, badan hukum perkumpulan sebagai pengelola rumah sakit bertujuan dalam menyelenggarakan pelayanan kesehatan mengedepankan fungsi sosial dibandingkan dengan fungsi ekonomi.

\section{Badan Usaha Pengelola Rumah Sakit Publik dan Privat}

Rumah sakit menikmati imunitas terhadap tuntutan hukum, hal ini disebabkan bahwa rumah sakit bersifat amal, sosial dan tidak mencari keuntungan ${ }^{4}$. Seiring dengan perkembangan zaman perubahan terjadi pada rumah sakit privat yang mulai kesulitan untuk menutup biaya pengeluaran yang lama makin besar serta tidak bisa lagi mengharapkan dari para dermawan. Maka demi kelangsungan berjalannya

\footnotetext{
${ }^{4}$ J. Guwandi, 2011, Hukum Rumah Sakit \& Corporate Liability, Badan Penerbit Fakultas Kedokteran UI, Jakarta, hlm. 8.
} 
pelayanan kesehatan rumah sakit privat sehingga harus memperhitungkan biaya-biaya yang harus dikeluarkan dan menagihnya pada pasien. Berkembang pesatnya teknologi kedokteran mengharuskan rumah sakit privat menggunakan teknologi yang menunjang pelayanan kesehatan, hal tersebut mengakibatkan modal rumah sakit privat terus bertambah dan juga mulai mengarah pada mencari keuntungan. Maka dilihat secara sosiologis, rumah sakit swasta sudah berubah dari status "sosial-murni" menjadi “sosial-ekonomis" demi kelangsungan hidup dan tujuannya5

Pasal 21 Undang-Undang Nomor 44 Tahun 2009 Tentang Rumah Sakit yaitu rumah sakit privat dikelola oleh badan hukum dengan tujuan profit yang berbentuk peseroan terbatas atau persero. Tujuan utama dari persero adalah bagaimana mendapatkan keuntungan yang sebesar-besarnya dengan modal yang sekecil-kecilnya, akan tetapi berbeda dengan perseroan khusus perumahsakitan karena perseroan mempunyai fungsi sosial.

Kewajiban menjalankan fungsi sosial perseroan rumah sakit yang dimaksud Pasal 29 ayat 1 huruf f Undang-Undang Nomor 44 Tahun 2009 Tentang Rumah Sakit yaitu melaksanakan fungsi sosial antara lain dengan memberikan fasilitas pelayanan pasien tidak mampu/miskin, pelayanan gawat darurat tanpa uang muka, ambulan gratis, pelayanan korban bencana dan kejadian luar biasa, atau bakti sosial bagi misi kemanusiaan.

Berdasarkan Pasal 74 Undang-undang Nomor 40 Tahun 2007 Tentang Perseroan terbatas menentukan:

1. Perseroan yang menjalankan kegiatan usahanya di bidang dan/atau berkaitan dengan segala sumber daya alam wajib melaksanakan Tanggung jawab Sosial dan Lingkungan.

2. Tanggung Jawab Sosial dan Lingkungan sebagaimana dimaksud pada ayat (1) merupakan kewajiban perseroan yang dianggarkan dan diperhitungkan sebagai biaya Perseroan yang pelaksanaannya dilakukan dengan memperhatikan kepatutan dan kewajaran.

3. Perseroan yang tidak melaksanakan kewajiban sebagaimana dimaksud pada ayat (1) dikenai sanksi sesuai dengan ketentuan peraturan perundang-undangan.

\footnotetext{
${ }^{5}$ J. Guwandi, 1991, Dokter dan Rumah Sakit, Badan Penerbit Fakultas Kedokteran UI, Jakarta, hlm. 9.
} 
4. Ketentuan lebih lanjut mengenai tanggung jawab sosial dan lingkungan diatur dengan peraturan pemerintah.

Dengan demikian rumah sakit yang berbentuk PT atau persero dalam kegiatan usaha dan pelayanannya tidak terlepas dari ketentuan tersebut yakni melaksanakan corporate social responsibility. Dalam pelaksanaanya bentuk kepedulian / CSR dari Rumah Sakit yang berbentuk PT atau Persero dapat dilakukan dengan berbagai macam kegiatan, misal berpartisipasi aktif dalam tanggap darurat pada saat terjadinya bencana, pengobatan gratis pada masyarakat kurang mampu, penyuluhan kesehatan pada masyarakat, pembinaan kesehatan lingkungan pada masyarakat disekitar lingkungan rumah sakit dan lain-lain.

Berdasarkan Peraturan Pemerintah Nomor 23 Tahun 2005 Tentang Pengelolaan Keuangan Badan Layanan Umum, BLU adalah instansi di lingkungan pemerintah yang dibentuk untuk memberikan pelayanan kepada masyarakat berupa penyediaan barang dan/atau jasa yang dijual tanpa mengutamakan mencari keuntungan dan dalam melakukan kegiatannya didasarkan pada prinsip efisiensi dan produktivitas. badan layanan umum bertujuan untuk meningkatkan pelayanan kepada masyarakat dalam rangka memajukan kesejahteraan umum dan mencerdaskan kehidupan bangsa dengan memberikan fleksibilitas dalam pengelolaan keuangan berdasarkan prinsip ekonomi dan produktivitas, dan penerapan praktek bisnis yang sehat.

Kelebihan utama dari instansi yang menerapkan badan layanan umum adalah semua pendapatannya baik dari kegiatannya ataupun hibah dapat digunakan langsung untuk membiayai badan layanan umum yang bersangkutan ${ }^{6}$. Secara umum asas badan layanan umum adalah pelayanan umum yang pengelolaannya berdasarkan kewenangan yang didelegasikan, tidak terpisah secara hukum dari instansi induknya.

Perkembangan pengelolaan rumah sakit, baik dari aspek manajemen maupun operasional sangat dipengaruhi oleh berbagai tuntutan dari lingkungan, yaitu antara lain bahwa rumah sakit dituntut untuk memberikan pelayanan kesehatan yang bermutu, dan biaya pelayanan kesehatan terkendali sehingga akan berujung pada kepuasan pasien. Tuntutan lainnya adalah pengendalian biaya. Pengendalian biaya merupakan masalah yang kompleks karena dipengaruhi oleh berbagai pihak yaitu mekanisme pasar, tindakan ekonomis, sumber daya manusia yang dimiliki

\footnotetext{
${ }^{6}$ Cecep Triwibowo, 2012, Perizinan da Akreditasi Rumah Sakit, Haiki, Yogyakarta, hlm. 157.
} 
(profesionalitas) dan yang tidak kalah penting adalah perkembangan teknologi dari rumah sakit itu sendiri. Rumah sakit pemerintah yang terdapat di tingkat pusat dan daerah tidak lepas dari pengaruh perkembangan tuntutan tersebut.

Badan layanan umum yang diterapkan oleh rumah sakit pemerintah pada dasarnya sebagai salah satu jalan kemandirian pengelolaan keuangannya dengan tujuan utama melayani kesehatan masyarakat secara paripurna tanpa membedakan status sosial maupun status ekonomi. Berbeda dengan pengelolaan rumah sakit privat yang berbadan hukum perseroan terbatas.

Badan hukum perseroan terbatas yang mengelola rumah sakit bertujuan memperoleh keuntungan yang sebesar-besarnya karena dianggap sebagai bisnis kesehatan. Tujuan mencari laba yang sebesar-besarnya tersebut diperkenankan berdasarkan pasal 21 Undang-Undang Nomor 44 Tahun 2009 Tentang Rumah Sakit, rumah sakit privat yang dikelola oleh badan hukum perseroan terbatas.

\section{Kesimpulan}

Badan hukum pengelola rumah sakit privat yang sesuai dengan fungsi sosioekonomi adalah yayasan dan perkumpulan, rumah sakit seperti ini membawa misi sosial dan karena itu tidak mencari keuntungan. Sumber dana untuk berjalannya kegiatan pelayanan kesehatan dari donasi atau sumbangan. Fungsi sosio ekonomi yang dijalankan oleh yayasan atau perkumpulan sebagai badan hukum pengelola rumah sakit privat mempunyai kelemahan yaitu terkait dengan tata kelola yang cenderung kurang efisien, tidak agresif dan kompetitif mengingat persaingan pengelolaan rumah sakit yang gencar dilakukan oleh rumah sakit privat yang berbadan hukum perseroan terbatas.

\section{Daftar Pustaka}

Cecep Triwibowo, 2012, Perizinan da Akreditasi Rumah Sakit, Haiki, Yogyakarta. Endang Wahyati Yustina, 2012, Mengenal Hukum Rumah Sakit, Keni Media, Bandung. J. Guwandi, 2011, Hukum Rumah Sakit \& Corporate Liability, Badan Penerbit Fakultas Kedokteran UI, Jakarta. 1991, Dokter dan Rumah Sakit, Badan Penerbit Fakultas Kedokteran UI, Jakarta. 
Man S. Satrawidjaja, 2010, Peseroan Terbatas Menurut Tiga Undang - Undang Jilid 1, Bandung : PT. Alumni.

Soerjono Soekanto, 1987, Pengantar Hukum Kesehatan, Cv. Ramedja Karya, Bandung.

Surya Utama, Memahami Fenomena Kepuasan Pasien Rumah Sakit Referensi Pendukung Untuk Mahasiswa, Akademik, Pimpinan, organisasi, dan Praktisi Kesehatan, Fakultas Kesehatan Masyarakat Universitas Sumatera Utara.

Undang-Undang Nomor 17 Tahun 2012 Tentang Perkoperasian

Undang-Undang Republik Indonesia Nomor 44 Tahun 2009 Tentang Rumah Sakit

Undang-Undang Nomor 16 Tahun 2001 sebagaimana diubah dengan Undang-Undang Nomor 28 Tahun 2008 Tentang Yayasan

Undang-undang Nomor 40 Tahun 2007 Tentang Perseroan Terbatas

Undang - Undang Nomor 19 Tahun 2003 Tentang Badan Usaha Milik Negara

Peraturan Menteri Kesehatan Nomor 920/Menkes/Per/XII/1986 tentang Upaya Pelayanan Kesehatan Swasta di Bidang Medik

Peraturan Menteri Kesehatan Nomor 084/Menkes/Per/II/1990 Tentang Perubahan atas Peraturan Menteri Kesehatan RI Nomor 920/Menkes/Per/XII/1986 Tentang Upaya Pelayanan Kesehatan Swasta di Bidang Medik

Peraturan Menteri Kesehatan Nomor 378 Tahun 1993 tentang Pelaksanaan Fungsi Sosial Rumah Sakit Swasta Peraturan Menteri Kesehatan RI Nomor 56/ MENKES/ SK/I/2005, sebagai Penyelenggara Program Jaminan Kesehatan Masyarakat Miskin (PJKMM/ASKESKIN).

Peraturan Pemerintah Nomor 23 Tahun 2005 Tentang Pengelolaan Keuangan Badan Layanan Umum 